\title{
EKSISTENSI AREA IMIGRASI PADA TEMPAT PEMERIKSAAN IMIGRASI DI INDONESIA
}

\author{
Oleh : \\ Gusti Ayu Made Widnyani ${ }^{1}$
}

\begin{abstract}
Area Immigration is an area that is in every Immigration Check Point (TPI) in which the functions of immigration especially related to the people's traffic inspection which coming in and out of a country and there are a restricted and a sterile area that can only be traversed by parties concerned like the passengers or crew whom will exit or entry Indonesian territory or official and authorized personnel. Arrangements regarding to the area of immigration set in Part Five, Article 22 paragraph (1) of Immigration Law determined that: In every Immigration Checkpoints assigned a specific area to immigration inspection is the area of immigration. The existence of the immigration area reflects the immigration service quality standards in a country. As an international area marked by yellow line (yellow line), the area of immigration has a position that is as important as the sovereignty of a country. Normatively, immigration area which available in each Immigration Check Point is the place and area that was authorized by the Ministry and has a legal status (legal standing) and legitimate in law. So that the existence of the immigration area is a representation of authority and sovereignty. But immigration area is less effective because of the legal instruments governing inadequate and also people have not been aware of law so that there are many violations happens in the immigration area.
\end{abstract}

Keywords : Immigration area, Immigration CheckPoinst, The functions of immigration

\begin{abstract}
Abstrak
Area Imigrasi merupakan area yang ada di setiap Tempat Pemeriksaan Imigrasi(TPI) dimana fungsi keimigrasian khususnya terkait dengan pemeriksaan lalu lintas orang yang masuk dan keluar suatu negara dilakukan dan merupakan area terbatas serta steril yang hanya dapat dilalui oleh pihak-pihak yang berkepentingan saja seperti para penumpang atau oleh awak alat angkut yang akan keluar atau masuk Wilayah Indonesia atau pejabat dan petugas yang berwenang. Pengaturan perihal area imigrasi diatur dalam Bagian Kelima, Pasal 22 ayat (1)UU Keimigrasian ditentukan bahwa: Di setiap Tempat Pemeriksaan Imigrasi ditetapkan suatu area tertentu untuk pemeriksaan Keimigrasian yaitu area imigrasi. Eksistensi area imigrasi mencerminkan standar kualitas pelayanan keimigrasian di suatu negara. Sebagai area internasional yang ditandai oleh garis kuning (yellow line), area imigrasi memiliki kedudukan yang sama pentingnya dengan kedaulatan suatu negara. Secara normatif, area imigrasi yang ada disetiap Tempat Pemeriksaan Imigrasi merupakan tempat dan area yang dilegalisasi oleh Menteri dan memiliki kedudukan hukum (legal standing) yang sah di mata hukum. Sehingga eksistensi area imigrasimerupakan representasi wibawa dan kedaulatan negara.Namun area imigrasi kurang efektif karena instrumen hukum

Mahasiswi Magister Ilmu Hukum Universitas Udayana, Denpasar, Bali, Alamat Jalan Pulau Nias 1B Sanglah-Denpasar, e-mail: ayuwidnyani28@gmail.com
\end{abstract}


yang mengatur belum memadai dan juga masyarakat belum sadar hukum sehingga masih banyak pelanggaran yang terjadi diarea imigrasi tersebut.

Kata Kunci : Eksistensi, Area Imigrasi, Tempat Pemeriksaan Imigrasi, Fungsi Keimigrasian

\section{PENDAHULUAN}

\subsection{Latar Belakang}

Area imigrasi Indonesia merupakan area yang ada disetiap Tempat Pemeriksaan Imigrasi (TPI) di Indonesia sebagai tempat untuk pemeriksaan perlintasan orang yang masuk dan keluar wilayah Republik Indonesia. Keberadaan area Imigrasi tersebut ditetapkan berdasarkan keputusan Menteri yang dalam hal ini oleh Menteri Hukum dan Hask Asasi Manusia RI.

Kewenangan Pengaturan perlintasan Orang dan Pengawasan Keimigrasian dalam Yurisdiksi Republik Indonesia merupakan kewenangan Keimigrasian, Institusi lainnya yang ada dibandara seperti Angkasa Pura, PT Pelindo, Pelni, hanya sebatas instrumen penyedia sarana dan prasarana fisik, tetapi kewenangan atau legalitas yang menyatakan sebagai tempat perlintasan masuk dan keluar wilayah negara RI berada pada otoritas Imigrasi.

Eksistensi area imigrasi di TPI adalah cerminan standar kualitas pelayanan keimigrasian, karena orang asing yang datang dan masuk ke suatu negara, maka area yang pertama kali ditemui adalah area imigrasi, oleh karena itulah area imigrasi disebut sebagai area kewibawaan dari suatu negara. Namun area ini sering kali tidak dipahami sebagai area yang khusus atau area steril, sehingga banyak orang yang tidak berkepentingan keluar masuk area imigrasi, dan terkesan area imigrasi tidaklah berbeda dengan area lainnya di bandara. Area Imigrasi merupakan suatu ruang di bandara, yaitu dimulai dari antrean pada ruang keberangkatan sampai dengan ke pesawat atau dari pesawat sampai dengan konter imigrasi (kedatangan) dimana dilakukan pemeriksaan keimigrasian.

Area imigrasi ini amat penting, sehingga sering disebut sebagai steril area atau dianggap sebagai wilayah interrnasional dalam artian sempit, dimana didalam area tersebut ditentukan apakah secara keimigrasian seseorang tersebut sudah keluar wilayah Indonesia atau sudah memasuki wilayah Indonesia. ${ }^{2}$

Tata letak desain (lay-out) juga berpengaruh terhadap eksistensi area imigrasi, di negara Indonesia posisi area ini kurang memenuhi standar, dan terkesan saling bersinggungan serta tumpang tindih dengan area lainnya sehingga kurang efektifdan masyarakat kurang respek terhadap keberadaan area imigrasi yang seharusnya area tersebut haruslah steril dan terbatas.

Penjelasan Undang-Undang Nomor 6 Tahun 2011 Tentang Keimigrasian Pasal 22 ayat (1) 
Sebagai area terbatas area imigrasi merupakan area yang hanya dapat dilalui oleh pihak-pihak yang berkepentingan diantaranya para penumpang dan awak alat angkut (Crew) yang akan meninggalkan atau memasuki wilayah Indonesia serta para pejabat dan petugas yang berwenang”. Ketentuan ini jelas mengamanatkan bahwa hanya pihak tertentu saja yang dapat berada di area imigrasi tersebut, dan orang yang tidak berkepentingan secara tegas tidak diperbolehkan lalu lalang untuk keluar masuk area tersebut.

Area Imigrasi yang merupakan area internasional ditandai oleh garis kuning (yellow line), yang berada didepan counter imigrasi dan area imigrasi memiliki kedudukan yang sama pentingnya dengan kedaulatan suatu negara, walaupun hanya sebatas garis imajiner, namun area tersebut memiliki representasi kewibawaan dari suatu negara, oleh karena itu area imigrasi ini memiliki kedudukan hukum (legal standing) yang jelas, sah dan harus dihargai serta dihormati sama halnya dengan wilayah internasional sebagai area masuk dan keluarnya orang ke dan dari suatu negara.

\subsection{Perumusan Masalah}

Dari latar belakang masalah yang diuraikan diatas dapat dirumuskan permasalahan sebagai berikut yaitu:

1. Bagaimana eksistensi area imigrasi pada Tempat Pemeriksaan Imigrasi di Indonesia.
2. Upaya-upaya apa yang perlu dilakukan pemerintah agar eksistensi area imigrasi efektif.

\section{METODE PENELITIAN}

Metode penelitian yang digunakan adalah penelitian normatif, dengan menggunakan pendekatan Perundang-undangan, Pendekatan Analisis Konsep Hukum serta menggunakan bahan hukum primer dan bahan hukum sekunder yang kemudian dianalisis melalui teknik deskripsi, teknik evaluasi selanjutnya diinterpretasi secara sistematis dan sosiologis terhadap kaidah hukum sehingga memperoleh kesimpulan terhadap permasalahan yang ada. Sumber hukum primer yaitu UU Keimigrasian dan peraturan-peraturan dalam bidang Keimigrasian yang berkaitan dengan permasalahan seperti Peraturan Pelak-sanaan UU Keimigrasian, dan bahan hukum sekunder yaitu bahan Hukum yang memberikan penjelasan terhadap bahan hukum Primer yang terutama adalah buku-buku hukum, jurnal hukum, rancangan UU, Karya ilmiah Ahli Hukum, dibantu dengan informasi via internet yang relevan dengan permasalahan yang diteliti sehingga bahan hukum sekunder ini dapat memberikan inspirasi dan petunjuk yang dapat dipakai sebagai acuan untuk menelaah persoalan yang ada. ${ }^{3}$

Peter Mahmud Marzuki, 2014, Penelitian Hukum Edisi Revisi, KencanaPrenadamedia Group, Jakarta, hlm., 196. 
Semua bahan hukum tersebut kemudian dianalisis melalui teknik deskripsi, teknik evaluasi yang selanjutnya diinterpretasikan secara sistematis dan sosiologis terhadap kaidah hukum yang ada untuk kemudian diperoleh suatu kesimpulan secara keseluruhan dari permasalahanpermasalan yang ada.

\section{HASIL DAN PEMBAHASAN}

3.1. Eksistensi Area Imigrasi Indonesia

Kehadiran area imigrasi

di beberapa tempat pemeriksaan imigrasi saat ini dirasa kurang efektif, mengingat masih belum adanya suatu ketentuan mengenai standar operasional prosedur dan tata letak area imigrasi di Indonesia dan masyarakat umum juga kurang paham dan kurang mengerti akan eksistensi area imigrasi sebagai area terbatas yang seharusnya tidak semua orang bisa melaluinya, sehingga terkesan kurang dihargai dan sering diabaikan oleh masyarakat.

Keberadaan area imigrasi di Indonesia harus diposisikan sebagai area yang berwibawa, bermartabat, bersih dan aman seperti bandar udara internasional di negara lain, dimana area imigrasi nya benar-benar steril dan hanya pihak yang berkepentingan saja yang dibolehkan masuk dan berada di area tersebut, hal ini tentu berbeda dan berbanding terbalik dengan kondisi bandara di Indonesia, dimana masih banyak orang-orang yang tidak seharusnya berada di area tersebut tapi sering memaksakan kehendak untuk masuk dan berada di area yang seharusnya terbatas hanya untuk penumpang, awak alat angkut, petugas dan pejabat C.I.Q (Customs, Immigration, Quarantine)

Relevan dengan hal tersebut diatas jika dikaitkan dengan Pengaturan perlintasan orang yang akan masuk serta akan keluar wilayah Indonesia, maka setiap orang yang memasuki wilayah Indonesia wajib melalui TPI (Tempat Pemeriksaan Imigrasi) yaitu baik itu Pelabuhan, bandara dan pospos lintas batas serta tempat lain yang bukan Tempat Pemeriksaan Imigrasi namun disahkan dan difungsikan sebagai TPI atas dasar persetujuan dan keputusan Dirjenim.

Memasuki wilayah RI tidak melalui TPI atau melalui TPI namun tidak melalui pemeriksaan oleh Pejabat Imigrasi atau tidak memiliki izin masuk maka tindakan tersebut dikatagorikan sebagai Illegal Entry dan merupakan tindakan yang dapat dipidana ${ }^{4}$.

Memasuki area steril yang berada didalam TPI dengan tanpa hak juga merupakan pelanggaran, karena area tersebut merupakan area dimana tidak sembarang orang bisa lalu lalang dan masuk melewati area tersebut, hanya para penumpang, awak alat angkut yang dalam hal ini para kru, petugas dibandara dan pejabat Imigrasi yang melaksanakan Tugas dan fungsi

\footnotetext{
4 M. Iman Santoso, 2004, Perspektif Imigrasi Dalam Pembangunan Ekonomi Dan Ketahanan Nasional, UI- Press, Jakarta, hlm., 19
} 
keimigrasian diwilayah perbatasan negara Indonesia yang bisa masuk ke area tersebut, namun sampai saat ini sanksi untuk orang yang melakukan pelanggaran yaitu memasuki area imigrasi tanpa hak belum ada dan belum diatur.

Pengaturan terhadap perlintasan orang yang akan memasuki ataupun yang akan keluar wilayah RI berlaku ketentuan dan peraturan keimigrasian Indonesia, antara lain: ${ }^{5}$

1. Perlintasan orang dianggap sah jika orang yang memasuki ataupun keluar dari wilayah negara R.I. mendapat izin masuk atau izin keluar dari Pejim (Pejabat Imigrasi) yang bertugas dan melakukan pemeriksaan Keimigrasian di TPI (Tempat Pemeriksaan Imigrasi)

2. Setiap orang asing yang melakukan perlintasankewilayah negara R.I. wajib memiliki Dokumen perjalanan yang sah dan masih berlaku.

3. Pejabat Imigrasi berwenang memeriksa setiap orang asing yang melakukan perlintasan baik yang masuk ataupun keluar wilayah Negara Republik Indonesia.

4. Pejabat Imigrasi berwenang untuk menolak ataupun memberi izin masuk atau izin keluar bagi orang asing yang melintas di wilayah Negara R.I.

John Sarodja Saleh, 2008, Sekuriti dan Intelijen Keimigrasian, Direktorat Jenderal Imigrasi Departemen Hukum dan HAM, Jakarta, hlm. 65.
Terkait dengan resistensi dan kurang efektifnya keberadaan area imigrasi di beberapa tempat pemeriksaan imigrasi saat ini, maka dengan menggunakan teori dari Lawrence M Friedman sebagai alat untuk menganalisis permasalahan yang ada, dimana ada 3 (tiga) subsistem hukum yang dipakai diantaranya yaitu : struktur hukum (The legal structure) substansi hukum (The legal substance) dan kultur hukum (The legal culture).

Struktur hukum merupakan elemen dasar nyata dan permanen dari sistem hukum ia adalah tubuh institusional. Jaditermasuk didalamnya institusi kepolisian dengan polisinya, institusi pengadilan dengan hakimnya dan institusi Direktorat Jenderal Imigrasi dengan pejabat imigrasi dan PPNS Imigrasi. Substansi hukum mengacu pada asas dan kaidah hukum atau mengenai norma, keseluruhan aturan hukum yang tertulis ataupun tidak tertulis dan tersusun dari peraturan-peraturtan maupun undangundang. Kultur hukum merupakan bagian budaya umum, yakni adat kebiasaan, pendapat, cara berpikir yang mengarah pada kekuatan-kekuatan sosial dari hukum dengan cara tertentu. Kultur hukum diibaratkan bahan bakar dari sebuah mesin. Menurut Lawrence M Friedman yang menyatakan there are three elements in legal systems, i.e: legal structure, legal substance, and legal culture: ${ }^{6}$

\footnotetext{
Lawrence M. Friedman, 1975, The Legal System A Social Science Perspektive, Rusell Sage Foundation, New York, p. 14
} 
1. The legal structure, is a law enforcement agency that is implementing the rule of law (Struktur hukum adalah institusi penegak hukum yang melaksanakan aturan.

2. The legal substance of the law refers to the principles and rules of law or the norms, rules and laws (Substansi hukum mengacu pada asas dan kaidah hukum atau mengenai norma, peraturan maupun undang-undang).

3. The legal culture is determined by the values of the reference in carrying out the law (Budaya hukum atau Kesadaran hukum ditentukan oleh nilai-nilai yang menjadi acuan dalam menjalankan hukum.

Jika membahas substansi keimigrasian dalam relevansinya dengan sistem hukum maka dapat diuraikan hal-hal berikut : ${ }^{7}$

a. Lembaga atau instansi penegak hukum keimigrasian dalam hal ini adalah pejabat internal dikalangan imigrasi, selain itu fungsi dan peran imigrasi sebagai pemberi pelayanan keimigrasian dalam artian terkait dengan struktur hukum (legal structure) merupakan acuan terhadap pembatasan dari keseluruhan instansi-instansi penegak hukum.

Santoso M.Iman, 2012, Perspektif Imigras Dalam Migrasi manusia, Pustaka Reka Cipta, Bandung, hlm., 126. b. Asas dan kaidah hukum keimigrasian (substansi hukum) (legal substance), merupakan keseluruhan aturan keimigrasian, norma, keputusan atau kebijakann keimigrasian yang dikeluarkan.

c. Persepsi masyarakat terhadap peraturan keimigrasian. Budaya hukum (legal culture), merupakan kekuatan sosial yang menjadi acuan bagaimana hukum itu digunakan, apakah menuju atau menjauh dari hukum atau disalahgunakan oleh masyarakat dengan cara-cara tertentu.

d. Implementasi Sarpras dalam proses penerapan peraturanperaturan keimigrasian.

Pertama; Struktur hukum yang dimaksud adalah instansi penegak hukum, dalam hal ini kalangan internal imigrasi yaitu Pejabat Imigrasi.

Sejauh ini, struktur hukum telah berjalan dengan baik. Pejabat Imigrasi yang bertugas dibandara baik diterminal kedatangan internasional maupun keberangkatan internasional telah menjalankan tugasnya dengan sangat baik dan bekerja sesuai SOP. Adanya pengawasan secara rutin oleh Pegawai Imigrasi yang ditugaskan dibandara mengamankan dan menjaga ketertiban antrean penumpang dan orang-orang yang melintas di ruang atau area imigrasi maupun oleh Kepala Bidang Pendaratan dan Izin Masuk selaku pejabat yang bertanggung 
jawab terhadap seluruh mekanisme pelayanan keimigrasian di bandara khususnya disekitar area imigrasi, menunjukann bahwa jajaran imigrasi telah berusaha semaksimal mungkin melaksanakan tugasnya. Namun, dalam kondisi tertentu, Pejabat Imigrasi yang bertugas di area imigrasi cenderung bersikap permisif dan mudah toleran terhadap masyarakat. Sehingga area imigrasi tersebut seringkali dimasuki oleh pihak-pihak yang tidak berkepentingan.

Kedua ; Substansi hukum, dimana instrumen hukum yang mengatur hal ikhwal area imigrasi saat ini belum cukup memadai. Area imigrasi hanya diatur dalam Bagian Kelima, Pasal 22 UU No. 6 Tahun 2011 tentang Keimigrasian. Dalam penjelasan pasalnya pun hanya tertulis "cukup jelas". walaupun di dalam penjelasan ayat (1) nya disebutkan batas area imigrasi dan pentingnya penetapan area tersebut mengingat di area tersebut dapat ditentukan status keimigrasian seseorang apakah merekasudah keluar dari wilayah Indonesia ataupun sudah memasuki wilayah Indonesia sehinggan area atau ruang yang ada di antrean kedatangan dan keberangkatan tersebut memegang peranan yang sangat besar.

Mengingat minimnya aturan yang mengatur tentang keberadaan area ini maka perlu dibuat aturan teknis, seperti Peraturan Pemerintah, Peraturan Menteri, ataupun Standar Operasional Prosedur (SOP) yang memuat soal area imigrasi. Bahkan dalam Peraturan Pelaksanaan UU Keimigrasian yang baru pun tidak diatur soal area imigrasi. Seharusnya Peraturan Pemerintah yang merupakan peraturan pelaksanaan dari UndangUndang maka substansi Peraturan Pemerintah tersebut seharusnya merupakan penjabaran lebih lanjut serta bersumber dari Undang-Undang dan agar undang-undang dilaksanakan sebagaimana mestinya.

Akibat minimnya pengaturan tentang area imigrasi, maka batasan soal terminology area imigrasi pun masih ambigu dan belum jelas. Kemudian masalah tata letak desain (lay-out) area imigrasi juga belum adanya keseragaman di bandarabandara di Indonesia dan belum adanya sanksi hukum bagi pihak yang keluar masuk area imigrasi secara ilegal, serta belum adanya standar prosedur pelaksanaan dilapangan.

Ketiga; Budaya hukum. Paham kesadaran hukum sebenarnya berkisar pada pikiran-pikiran yang menganggap bahwa kesadaran hukum dari warga masyarakat merupakan suatu faktor yang menentukan sahnya hukum. ${ }^{8}$

Menurut pendapat Soerjono Soekanto kesadaran hukum adalah penilaian terhadap apa yang dianggap baik dan yang tidak baik, ${ }^{9}$

Soerjono Soekanto, 2011, Hukum Adat Indonesia, PT RajaGrafindo Persada, Jakarta, hlm. 310

Soerjono Soekanto, 1982, Suatu Tinjauan Sosiologi Hukum Terhadap Masalah-Masalah Sosial, Alumni, Bandung, hlm. 184. 
Sehingga dapat dikatakan kesadaran tersebut telah mendarah daging dan mempunyai kekuatan yang lebih besar dari pada wewenang biasa yang didasarkan prestise. Jadi kesadaran hukum masyarakat belum menjamin masyarakat tersebut akan mentaati hukum, hal ini disebabkan berbagai kepentingan, kesadaran hukum relevan dengan ketaatan atau efektivitas hukum, apakah ketentuan hukum itu sudah benar-benar berfungsi atau tidak didMasyarakat pengguna fasilitas bandara belum sepenuhnya mengerti dan belum sepenuhnya sadar hukum, dalam artian kesadaran hukum masyarakat Indonesia masih rendah, aturan hukum sudah ada, namun tidak sedikit dari mereka yang kadang suka memaksa-maksa petugas untuk bisa masuk ke area imigrasi. Hal ini tentu sangat disesalkan, dimana Pejabat Imigrasi sudah berusaha maksimal dan berusaha memberikan pelayanan yang terbaik, terkadangmasihadamasyarakat yang selalu mendesak untuk diberikan izin masuk. Masyarakat kita perlu diberi pemahaman hukum, sehingga aturan yang telah dibuat dapat ditaati dan dipatuhi dengan baik.

\subsection{Upaya-upaya apa yang perlu dilakukan pemerintah agar eksistensi area imigrasi efektif.}

Banyak perlawanan dan pelanggaran terhadap eksistensi area imigrasi di setiap TPI sehingga perlu dilakukan pembenahan dan koordinasi lintas sektoral agar kehadiran dan keberadaan area steril ini lebih dihargai.

Mengenai resistensi dari dialami oleh beberapa Tenaga Kerja Indonesia (TKI) yang telah mendapat tanda keluar oleh Pejabat Imigrasi, bahkan sudah berada di dalam pesawat, ternyata diperintahkan turun dari pesawat oleh pihak Kepolisian karena diduga TKI ilegal. Hal ini terjadi karena kurangnya koordinasi dan terjadi ketidaksepahaman pihak Kepolisian dengan pihak imigrasi tentang arti penting eksistensi area imigrasi. Logika hukumnya, jika sudah berada di boarding room berarti mereka sudah melalui pemeriksaan keimigrasian serta telah diberikan tanda bertolak, apalagi jika sudah berada di dalam pesawat, itu berarti mereka sudah berada di area internasional, dan seharusnya tidak boleh dilakukan proses penangkapan, hal tersebut tentu tidak dibenarkan, para TKI itu perlu mendapat perlindungan hukum karena mereka statusnya sudah berada di area internasional, ini menunjukkan betapa area imigrasi sama sekali tidak dianggap dan tidak ada wibawa serta koordinasi lintas sektoral sama sekali tidak ada.

Melihat realita dan adanya resistensi terhadap keberadaan area imigrasi di Indonesia, maka perlu dilakukan upaya-upaya pembenahan oleh pemerintah, diantaranya perlu adanya pengaturan yang lebih baik 
dan juga penjabaran aturan hukum teknis soal area imigrasi, perlu dibuat Juklak dan juga Juknisnya sehingga pelaksanaan dilapangan menjadi lebih baik dan tidak menimbulkan kesalahpahan serta tidak multitafsir.

Dalam hal ini Pembentuk undang-undang (wets gever) harus sadar dan memahami bahwa begitu pentingnya eksistensi area imigrasi, termasuk didalamnya tata letak area imigrasi, sanksi hukum bagi para pihak yang melakukan pelanggaran dan juga dibuatkan suatu Standar Operasional Prosedur (SOP) sebagai pegangan bagi para Petugas dilapangan sehingga jangan sampai terjadi konflik diwilayah atauarea imigrasi. Selainhal diatas yang perlu dilakukan adalah peningkatan kesejahteraan pegawai imigrasi yang bertugas dibandara, mengingat beban kerja yang berat dan jadwal kerja yang padat, maka para Pejabat Imigrasi yang bertugas di area imigrasi perlu dijamin kesejahteraannya, karena biaya hidup yang tinggi selama bertugas di bandara dan tanggung jawabdan resiko yang besar yang harus diemban, maka kesejahteraan mereka harus dijamin.

Hal lain yang perlu dilakukan adalah dengan mengadakan sosialisasi terhadap masyarakat serta perusahaanperusahaan penerbangan dan petugas dibandara agar lebih memahami pentingnya mematuhi aturan dan menghormati area imigrasi serta agar masyarakat bisa lebih berbudaya dan sadar hukum. Kesadaran hukum masyarakat kita masih rendah, sehingga sosialisasi secara rutin serta koordinasi lintas sektoral dan pendekatan personal, perlu dilakukan agar masyarakat memahami betapa pentingnya wibawa area imigrasi, yang merupakan representasi dari suatu negara dan kedaulatan negara.

\section{PENUTUP}

\subsection{Simpulan}

Secara yuridis pengaturan perihal area imigrasi sudah diakomodir dalam UU Keimigrasian yang baru dimana disebutkan area imigrasi bersifat terbatas dan steril sehingga hanya orang-orang tertentu saja yang bisa melewati area tersebut, diantaranya para penumpang, kru atau awak pesawat yang akan melakukan perjalanan keluar negeri atau pun yang akan memasuki wilayah Indonesia atau juga pejabat dan petugas yang berwenang. Ketentuan ini jelas mengamanatkan bahwa hanya pihak tertentu saja yang dapat berada di area tersebut, sedangkan orang yang tidak berkepentingan secara tegas tidak boleh keluar atau masuk area imigrasi. Namun area imigrasi tersebut keberadaannya belum efektif, mengingat masih banyak orang yang tidak berkepentingan masuk dan keluar dengan leluasa, hal ini disebabkan karena minimnya pengaturan tentang area imigrasi dan juga belum adanya aturan teknis, seperti Peraturan Pemerintah, Peraturan Menteri, ataupun Standar Operasional Prosedur (SOP) yang memuat soal area imigrasi. 
Bahkan dalam Peraturan Pelaksanaan pun tidak mengatur tentang area imigrasi. Selain itu Kesadaran hukum masyarakat kita masih rendah, aturan hukum sudah ada, namun tidak sedikit dari mereka yang memaksa-maksa petugas untuk masuk ke area imigrasi. Serta belum adanya sanksi hukum yang memberi efek jera bagi para pihak yang melanggar ketentuan masuk atau keluar area imigrasi secara illegal.

\subsection{Saran}

Agar dibuat aturan hukum tentang area imigrasi yang dituangkan dalam Peraturan Pemerintah, Peraturan Menteri, dan juga dituangkan dalam Juklak dan Juknis ataupun Standar Operasional Prosedur (SOP) yang memuat soal area imigrasi dan hendaknya Peraturan Pelaksanaan UU Keimigrasian mengatur soal area imigrasi serta dimuat sanksi hukum bagi para pihak yang keluar masuk area imigrasi secara illegal.

\section{DAFTAR BACAAN}

\section{BUKU}

Peter Mahmud Marzuki, 2014, Penelitian Hukum Edisi Revisi, Kencana Prenadamedia group, Jakarta

Lawrence M. Friedman, 1975, The Legal System A Social Science Perspektive, Rusell Sage Foundation, New York, p. 14

M. Iman Santoso, 2004, Perspektif Imigrasi Dalam Pembangunan Ekonomi Dan Ketahanan Nasional, UI- Press, Jakarta
M.Iman Santoso, 2012, Perspektif Imigrasi Dalam Migrasi manusia, Pustaka Reka Cipta, Bandung.

Soerjono Soekanto, 2011, Hukum Adat Indonesia, PT RajaGrafindo Persada, Jakarta, hlm. 310

Soerjono Soekanto, 1982, Suatu Tinjauan Sosiologi Hukum Terhadap Masalah-Masalah Sosial, Alumni, Bandung

John Sarodja Saleh, 2008, Sekuriti dan Intelijen Keimigrasian, Direktorat Jenderal Imigrasi Departemen Hukum dan HAM, Jakarta

\section{PERUNDANG-UNDANGAN}

Undang-Undang dan Penjelasan UU

Nomor 6 Tahun 2011 Tentang Keimigrasian

Peraturan Pemerintah Republik Indonesia Nomor 31 Tahun 2013 Tentang Peraturan Pelaksanaan UU Nomor 6 Tahun 2011 Tentang Keimigrasian. 